\title{
On Cultivation of Autonomous Learning Competence in College English Listening Teaching*
}

\author{
QIN Jing \\ Binzhou University, Binzhou, China
}

\begin{abstract}
One of the important aspects of new education curriculum reform in China is to promote students' learning style, that is, to change from the center of the teachers "giving-receiving" education gradually to the center of students "autonomic learning". Although it is a common view that autonomous learning will efficiently improve the ability of learners, it remains blank in the area of listening teaching. This paper makes a brief introduction on autonomous learning and makes concrete analysis of the definitions of autonomous learning. It also analyzes the factors affecting English listening and the problems in listening teaching in colleges and proposes effective measures and suggestions. This paper attempts to validate the effectiveness of autonomous learning in college English teaching, which can serve as guidance for both teachers and students.
\end{abstract}

Keywords: autonomous learning, college English, listening teaching

\section{Introduction}

Though it is important, it seems that listening does not obtain enough attention from both students and teachers in China's English language teaching and learning. Listening teaching still does not go beyond the stage of play-the-tape-and--check-the-answers. Such English listening lessons give no instruction as to how to go about listening, but just test the students' listening ability. They are by no means an efficient way to radically advance the students' listening ability. Under this situation, more and more attention is being drawn to autonomous learning. As China's autonomous learning theory started later, most scholars borrowed foreign definitions and perfected them or synthesized a variety of viewpoints and comprehension according to their own understandings. Besides, in China English autonomous learning theory system is not perfect and research methods are not mature. Under this situation, the author attempts to study the cultivation of autonomous learning competence in college English listening teaching. Autonomous learning competence training is one of the important tasks of college English reform, and one of the important ways to enhance the listening teaching effect. Only by respecting the students' subjectivity and initiative and training students' autonomous learning competence, can the modern language aim be truly achieved.

\section{Definitions of Autonomous Learning}

In our daily teaching, the terms about autonomous learning are often heard, but few of us really perceive what the autonomous learning is. We could quote from Henri Holec (1981)'s book, Autonomy and Foreign

\footnotetext{
* Acknowledgements: The research project number of this paper is Bzxyrw1209. QIN Jing, lecturer, M.A., Foreign Languages Department, Binzhou University.
} 
Language Learning, describing it as "the ability to take charge of one's learning" (p. 13), which is regarded as launching points for research in this field. He considers autonomous learning ability mainly reflecting in five areas: first, determining the objectives; second, defining the contents and progressions; third, selecting methods and techniques to be used; fourth, monitoring the procedures of acquisition; fifth, evaluating what has been acquired (Heloc, 1981). Zimmerman as an authority autonomous learning psychologist of the United States put forward that as long as the student is an active participant in three aspects of meta-cognition, motivation, behavior, then his learning is autonomous (Bound, 1988). Meta-cognition includes planning, monitoring, and regulating activities. Motivation is that students become active knowledge learner whose thoughts changing from "want me to learn" to "I want to learn". They all regard themselves as effective self-regulatory persons. Behavior indicates students can build the best conducive environment to learn independently.

Most scholars agreed that the autonomous learning should be learner-centered and learning is a process of self-construction, including self-planning, self-management, self-regulating, self-inspection, self-feedback, and self-evaluation according to students' different needs in the process of their own learning, although there are different opinions on the understanding and definition of autonomous learning between the domestic and foreign scholars.

\section{Factors Affecting Autonomous Learning in College English Listening Teaching}

\section{Learners' Attitudes Towards English Listening}

Attitudes can be classified as items of social knowledge that are continually formed, strengthened, and modified, as a means of adjusting to and making changes in the social environment. Students' interest in learning may result in positive attitudes because they think what they are learning is interesting. As long as students hold a positive attitude towards English listening, they will pay more attention to the learning task and prefer to set their own goals for learning. Consequently, positive attitudes will lead to integrative motivation, certainly helping students foster their autonomous learning ability. So in order to develop students' autonomous learning ability, teachers should manage to change students' attitudes towards English learning.

\section{Learners' Motivation}

Most scholars seem to agree that motivation is one of the key factors that influence the rate and success of foreign language learning. Motivation provides the primary impetus to learn the second language and later the driving force to maintain the long and often tedious learning process.

There has been a very controversial issue on the relationship between autonomy and motivation in language learning, whether it is autonomy that enhances motivation or it is motivation that produces autonomy. By carrying out a large-scale study, Dickinson claimed that "motivation may lead to autonomy or be a precondition for it", which is crucial for the task of language learners' training (Dickinson, 1992). It indicates where teachers should choose to place their teaching emphasis. Teachers may advocate autonomy by encouraging students' motivation to learn in situations where learners resist autonomous practices or avoid learning opportunities.

\section{Learners' Meta-cognitive Knowledge}

Meta-cognition is any knowledge or cognitive process that monitors or controls any aspect of cognition. Learners' meta-cognitive knowledge includes learners' ideas about his cognitive process, students' knowledge, and awareness of themselves as language learners, of factors affecting language learning, and of the nature of 
language learning and teaching. A series of studies on learners' meta-cognitive knowledge have pointed out that learners' perceptions of language learning may have a significant influence on their learning outcomes (Broady, 1996). Students, who hold insightful beliefs about language learning processes, tend to develop a more active autonomous attitude that allows them to take charge of their learning whatever the situation may be. Though sometimes autonomous learning in language learning is described as a Western concept unfit to contexts such as those in East Asia, yet many Eastern Asian students agree with the Confucian belief that success in education is dependent not so much on innate ability as on individual effort and self-discipline. There is no doubt that learners armed with such a belief are more ready and willing for autonomy than other learners having no confidence in the results of their self-effort and self-discipline.

\section{Learners' Individual Differences}

Individual differences influence learners' reaction to their language study as well as their preference with respect to the nature and organization of learning activities, which are essential elements in autonomous learning (Dam, 1995). In the process of learning a language, learners may be not able to express themselves with the clarity, confidence, or authority, but certain degree of self-esteem can help learners regulate their language production, especially their oral production, which is a significant part of language learning. Anxiety is one of the most complex affective factors in second language acquisition. A language learner is likely to be successful if he can choose proper learning strategies in his learning process and properly uses the strategies. The more frequent a learner resorts to learning tactics, the more prosperous his learning may be. Students should be provided with more strategy training so as to perfect their English proficiency and develop the ability of autonomous learning. Besides, it is essential for learners to use assessments as a way to evaluate the effectiveness of self-access learning. Even on a small scale, self assessments can make learners reassess their approach or motivate them to further study by providing them with feedback on how they are doing.

\section{Problems in English Listening Teaching in Colleges}

\section{Unsuitable Listening Materials}

First and foremost, many listening materials used are not adaptive for the listening teaching indeed. Teachers often use the recorded materials of written language, which are usually selected from standards English lack of the spoken language and difficult to understand. The listening materials often have less contact with the reality and specific situation. The words are usually far away from the authentic and natural language in real life, which is unfavorable to enhancing students' listening ability. Students who are adapt to this kind of slow and clear English usually fail to follow the rate of speech and fail to understand idioms, slang, and locutions used by native speakers. They will find it difficult to catch what native speakers say or communicate with English native speakers in real-life situation, even though some can obtain high marks in listening tests.

\section{Lacking Innovative Teaching Techniques or Classroom Activities}

Traditional teaching techniques or classroom activities do not follow the interactive nature of listening comprehension and lack interaction. Listening activities in the classroom are carried out in the same way as in tests because of insufficient research on the appropriate teaching means. The listening classes are usually conducted in this way, as teacher plays the tape, students listen to it, and then do some exercises (usually 20 multiple-choice), and finally, the teacher checks the answers. Teachers usually concentrate more attention on correcting answers of the listening materials, neglecting the interactive feature of listening process and ignoring 
the various feelings and personality between the students. This kind of listening method often depresses the students and makes them feel wearisome and tired of learning English listening, failing to make students learn to use listening strategies. Although some students may obtain high marks in the traditional listening test, most of the students lose taste in learning or do not know how to conquer their own problems encountered in the process of listening. Gradually, they will feel abandoned by the teachers and feel anxious in learning. What is worse, they may feel frustrated and abandon listening. The result of this type of listening teaching is of course unsatisfactory.

\section{Suggestions on Autonomous Learning in College English Listening Teaching}

\section{Designing Listening Activities in English Listening Class}

Lack of background knowledge and linguistic knowledge are found to be great problems for successful listening comprehension. Teachers should pay more attention to the designing of listening activities. In second language teaching, Cook (1996) holds that "perhaps listening cannot be trained directly and the best thing teachers can do is devising amusing activities during which the natural listening processes can be automatically activated" (p. 261). Therefore, the designing of classroom activities is full of meaning in listening comprehension instruction. Benson (1997) divides the teaching of listening into three stages: pre-listening, while-listening, and post-listening. Let's look at the designing of classroom listening activities at these three different stages.

Pre-listening activities. Listeners will find it difficult to guess and interpret meaning when they are unfamiliar with the background knowledge. The major suggestion here for listening teaching is providing them with appropriate vocabulary through activities such as word association practice so that existing prior knowledge can be activated and missing knowledge can be introduced. When a piece of listening is presented, the vital first step has been ensured that this is teaching not testing. Through pre-listening activities, such as a discussion of the general background, students will activate their prior knowledge. This process is vital to learning in general, including listening. At the pre-listening stage, the teacher should make clear of the purpose, helping students comprehend the context and the topic, as well as asking students to express attitudes towards that topic, which will certainly activate relevant information and bring to the front of their minds anything that they already know about the topic. What is more, the students will use some of the less familiar words in the materials which will surely help the students to cope with the appearance of new words.

While-listening activities. During listening, students should hold an authentic purpose for listening and be encouraged to understand the text more intensively or more extensively for gist or specific information. Learning activities include following the information, guessing the meaning of unfamiliar words in contexts, responding to views expressed, reflecting on what is said, taking general notes, or writing down specific points.

Post-listening activities. Students have a more intensive study, for example, intensive listening for note-taking and summarizing the content at the post-listening stage. Post-listening can also mix with other methods through the development of the topic into reading, speaking or writing activities. Students can work in small teams to communicate their understandings and construct key questions after hearing the text. This kind of cooperation can be highly motivated and offer good opportunities to practice listening.

\section{Methods of Overcoming the Major Listening Difficulties for Students}

Emphasize students' linguistic knowledge and pronunciation. In order to be a good listener, it is necessary for students to have a wide range of vocabulary and a good knowledge of grammatical structures as 
well as other linguistic features which enable listeners to process the listening materials more accurately and more easily. All in all, vocabulary is a major component of listening ability. Students should be encouraged to develop strategies for guessing word meanings from contextual clues and background knowledge.

Use mental techniques and self-monitoring to lessen anxiety. Some students are unable to concentrate on the coming new information, thus generating more difficulties in comprehension. Under this situation, teachers should first make it explicit that when they listen, they do not need to catch every word to understand a sentence, and figure out every sentence to get the whole meaning. We usually make intelligent guesses so as to understand incoming information with the help of our linguistic knowledge. So there is no need to be anxious when we miss some words, phrases, or sentences. Teachers should guide students to regard difficult tasks as challenges rather than dangers and assist them to regain confidence after setbacks. In addition, the students should be fully aware that language anxiety can be transient and by using mental techniques (self-talk) and self-monitoring might help in tackling this problem.

Identify purpose and build mental linkage. It is an effective way to cope with the sixth problem by combining individual pieces of information into larger units. Other memory strategies also play important roles in dealing with this problem. We can build mental linkages by relating new information to concepts already in memory, or relating one piece of information to another, using meaningful visual information, or employing actions to help memorize information that we hear. After clearly identifying the purpose, the listeners can figure out what they are listening for and wipe out potential useless information, thus lightening the burden of working memory.

\section{Conclusion}

Traditionally, teachers hold the opinion that listening comprehension is not something that can be taught, but something that learners master through constant practice with listening tests. Therefore, teachers simply provide students with various listening materials. The appearance of new words, anxiety, failing to understand sentences composed of familiar words and unfamiliar topics are found to be major difficulties obstructing students' listening comprehension. The research brings about some deep insights into the listening process as well as throws some light on the adjustment of listening teaching methods. By designing listening activities in English listening class and leading students to master some effective methods, college English teachers can help students cultivate autonomous learning in English listening teaching.

\section{References}

Bound, D. (1988). Developing student autonomy in language learning. London: Kogan Page.

Broady, E., \& Kenning, M. (1996). Promoting leaner autonomy in university language teaching. London: The Association for French Studies in Association With the Centre for Information on Language Teaching and Research.

Dam, L. (1995). Learner autonomy: From theory to classroom practice. Dublin: Authentic.

Dickinson, L. (1992). Learner autonomy: Learner training language learning. Dublin: Authentic.

Holec, H. (1981). Autonomy and foreign language learning. Oxford: Pergamon Press. 